\title{
“COBRA-DE-VIDRO”: DRAMATURGIA DE CHICO BUARQUE E RUY GUERRA NO ENSINO FUNDAMENTAL
}

\section{“COBRA-DE-VIDRO": DRAMATICITY OF CHICO BUARQUE AND RUY GUERRA IN ELEMENTARY SCHOOL}

\author{
Anna Maria Ribeiro F. M. Costa* \\ Rosemar Eurico Coenga**
}

\begin{abstract}
Resumo: Este estudo tem como objetivo apresentar aos Anos Finais do Ensino Fundamental uma proposta didático-pedagógica baseada no gênero dramático, aplicada nas disciplinas de História e Linguagens, no estabelecimento de uma discussão sobre formação do leitor e dramaturgia. Com base metodológica eminentemente bibliográfica, nas discussões sobre dramaturgia, leitura e formação de leitor, seguimos Grazioli (2007, 2015, 2019), Rösing (2005) e Zilberman (2005); Silva (2004), Zappa (2011) e Ramos e Miranda (2012) para os dados biográficos de Chico Buarque e Ruy Guerra. Sobre a invasão holandesa no Brasil e da atitude de Calabar em apoiar os holandeses, estudamos Guerra (1986), Schalkwijk (2000), Vainfas (2000) e Fausto (2007). Este trabalho pode subsidiar professores de Linguagens e de História, no que tange a um conhecimento sistematizado em literatura no Ensino Fundamental. Aos alunos, para além dos componentes curriculares, almejamos atender aos compromissos da Educação Básica concernentes aos direitos éticos, estéticos e políticos.
\end{abstract}

Palavras-chave: Ensino Fundamental. História. Literatura. Calabar: o elogio da traição. Dramaturgia.

\begin{abstract}
This study aims to present to the Final Years of Elementary School a didactic-pedagogical proposal based on the dramatic genre, applied in the disciplines of History and Languages, in the establishment of a discussion about the formation of the reader and dramaturgy. In this paper, we present Grazioli (2007, 2015, 2019), Rösing (2005) and Zilberman (2005) and Silva (2004), Zappa (2011) and Ramos and Miranda (2012) for the biographical data of Chico Buarque and Ruy Guerra. Regarding the Duth invasion in Brazil and Calabar's atitude in supporting the Dutch, we studied Guerra (1986), Schalkwijk (2000), Vainfas (2000) and Fausto (2007). This work can subsidize teachers of Languages and History, regarding a systematized knowledge in literature in Elementary School. To the students, in addition to the curricular components, we aim to meet the commitments of Basic Education regarding ethical, aesthetic and political rights.
\end{abstract}

Keywords: Elementary Education. History. Literature. Calabar: o elogio da traição. Dramaturgy.

\section{Abre o pano: introdução}

"A história é uma colcha de retalhos." Bárbara, personagem de "Calabar: o elogio da traição".

Como nos faz saber Jacques Le Goff (1992, p. 48), a "história da História não se deve preocupar apenas com a produção histórica profissional, mas com todo um conjunto de fenômenos que constituem a cultura histórica ou, melhor, a mentalidade histórica de uma época." O que o historiador nos permite é analisar os papéis de homens e mulheres em diferentes tempos, em diferentes circunstâncias e, o mais arrebatador, a possibilidade de reescrever histórias, de encontrar diferentes resultados. É o que

\footnotetext{
* Doutora em História pela Universidade Federal de Pernambuco (UFPE), professora do Univag Centro Universitário de Várzea Grande-MT, membro do Instituto Histórico e Geográfico de Mato Grosso. Email: anna-edu@hotmail.com

${ }^{* *}$ Doutor em Teoria Literária e Literaturas pela Universidade de Brasília (UnB). Docente do Programa de Pós-graduação e Ensino da Universidade de Cuiabá e Instituto Federal de Mato Grosso (UNIC/IFMT). Email: rcoenga@gmail.com
} 
pretendemos com os fatos que envolvem o personagem seiscentista da história colonial brasileira, Domingos Fernandes Calabar, "nascido durante a primeira década do século XVII, filho de pai português e de mãe indígena, de nome Ângela Álvares. Era, assim, um mameluco, e foi batizado numa igreja da paróquia de Porto Calvo." (SCHALKWIJK, 2000, p. 1). Na fala de Mathias de Albuquerque, governador das capitanias de Pernambuco, Itamaracá, Paraíba e Rio Grande representava um

um mulato bonito, pelo ruivo, sarará. Guerreiro como ele não sei mais se haverá. Onde punha o olho punha a bala. Onde o mangue atola, o pé firmava. Bom de briga, de mosquete e de pistola. Lia nas estrelas e no vento. Tendo a mata no peito e o peito atento, sabia dos caminhos escondidos. (BUARQUE; GUERRA, 1974, p. 10).

Nesse caminhar, lançamos nosso olhar investigativo para Calabar: o elogio da traição, título de uma peça de teatro musicada de Chico Buarque e Ruy Guerra (BUARQUE; GUERRA, 1974). Escrita em 1973, há registros ter sido um dos maiores investimentos teatrais da época, a empregar quase uma centena de pessoas. Entretanto, em outubro de 1974, o general Antônio Bandeira, Comandante do III Exército na fase mais repressiva da ditadura, proibiu a peça teatral após a montagem do espetáculo e da liberação da primeira versão do texto. Foi estreada somente em 1980, depois de ser liberada pela censura do regime civil-militar que perdurou até 1985, quando Tancredo Neves foi eleito presidente do Brasil pelo Colégio Eleitoral, em resposta à derrota da campanha pelas Diretas Já.

Em consonância com nossas áreas de formação acadêmica, propomos um diálogo entre a Literatura e a História, entre os textos dramatúrgicos e históricos, para estudar as invasões holandesas no Brasil, ocorridas no século XVII no Nordeste do Brasil. Para o historiador Boris Fausto (2007, p. 84), esse fato histórico consistiu

no maior conflito político-militar da Colônia. Embora concentradas no Nordeste, elas não se resumiram a um simples episódio regional. Ao contrário, fizeram parte do quaro das relações internacionais entre os países europeus, revelando a dimensão da luta pelo controle do açúcar e das fontes de suprimento de escravos.

Por meio da dramaturgia, a peça teatral Calabar: o elogio da traição, que conta com mais de vinte edições, consiste em um rico complemento ao conteúdo do livro didático. Esse momento ocorre no $7^{\circ}$ ano do Ensino Fundamental, quando a Base Nacional Comum Curricular (BNCC) de História dos Anos Finais Ensino Fundamental apresenta suas unidades temáticas, bem como no Ensino Médio, nos conteúdos de História do Brasil - Brasil Colônia. A exemplo de nossa proposta em estudar a invasão holandesa em terras brasileiras, quando são examinadas com mais profundidade as conexões entre Europa, América e África e "são debatidos aspectos políticos, sociais, econômicos e culturais ocorridos a partir do final do século XV até o final do século XVIII." (BNCC, 2018, p. 418).

Com base metodológica eminentemente bibliográfica, no campo da Literatura, seguimos os caminhos teóricos de Grazioli (2007, 2015 e 2019), Rösing (2005) e Zilberman (2005) para dar suporte às discussões sobre dramaturgia, leitura e formação de leitor. Nossa preocupação em apresentar dados biográficos de Chico Buarque e Ruy Guerra que atendessem a proposta deste estudo buscou Zappa (2011), Silva (2004) e 
Ramos e Miranda (2012). Para a compreensão dos porquês da invasão holandesa no Brasil, com ênfase em Domingos Fernandes Calabar, figura central da peça teatral do carioca da gema Chico Buarque e do moçambicano Ruy Guerra, fizemos uso dos estudos de Guerra (1986), Schalkwijk (2000), Vainfas (2000) e Fausto (2007). Todos discutindo também a opção de Calabar em apoiar os holandeses em detrimento aos portugueses e colonos brasileiros contra a Coroa portuguesa, crime pelo qual foi condenado, enforcado e esquartejado com a irrogação da pecha de traidor, em 22 de julho de 1635 .

Na peça de Chico Buarque e Ruy Guerra, as narrativas "são construídas pelos mais diferentes historiadores, quando podemos perceber como cada um deles segue seu propósito particular e apresenta-nos versões distintas de um mesmo conjunto de fatos, escolhendo seus heróis e vilões." (NUNES, 2002, p. 34). Nas palavras de Bárbara, mulher de Calabar, personagem de Chico Buarque e Ruy Guerra (1974, p. 119), "a história é uma colcha de retalhos". Na reescrita da História, usam a técnica do recorte de diversos trechos de livros históricos, a fim de fazer uma remontagem, demonstrado na voz de Bárbara que qualifica a peça organizada em colagem e justaposição de imagens e épocas, uma "montagem de palavras" (BUARQUE; GUERRA, 1974, p. 119). A intertextualidade também aparece ao se perceber uma relação evidente com o país dos militares e, ainda, na analogia entre Calabar e Carlos Lamarca (SILVA, 2004, p. 74-75).

A peça teatral Calabar: o elogio da traição, muito além de encenar um fato histórico ocorrido no Nordeste brasileiro no século XVII, quer discutir o conceito de traição a partir de Domingos Fernandes Calabar. E, ainda, uma crítica ao governo militar que provoca uma revisão da História. Quer contestar o regime militar então vigente, atos de censura, veículos de comunicação que espalham à sociedade brasileira interpretações que mudam o sentido do momento sociopolítico que, ao contrário, precisava ser questionado.

No $7^{\circ}$ ano do Ensino Fundamental (e, também, no Ensino Médio), o estudo das conexões entre Europa, América e África e da presença holandesa no Nordeste do Brasil colonial (1624-1654) podem atender aos propósitos do campo artístico-literário, contemplado na disciplina de Língua Portuguesa. Significa que a experiência da Literatura, da Arte e da História, aproximada por uma proposta interdisciplinar com a finalidade de não somente contemplar os conteúdos programáticos, mas também alcançar um potencial transformador e humanizador ao alunado. Estudar a figura de

Domingos Fernandes Calabar no contexto da invasão holandesa possibilitará ao aluno "inferir a presença de valores sociais, culturais e humanos e de diferentes visões de mundo, em textos literários" [...]. (BNCC, 2018, p. 159). Como resultado, espera-se dos alunos a geração de sua autonomia na experiência escolar, quando terão condições de se tornarem sujeitos de seu processo de ensino-aprendizagem, adotando posturas críticas, empenhadas e colaborativas em sala de aula e fora dela.

\section{Dramaturgia para juventude: uma proposta de leitura}

Ao propormos analisar as contribuições do texto dramatúrgico Calabar: o elogio da traição, de Chico Buarque e Ruy Guerra, vislumbramos contribuir na formação do leitor na perspectiva do letramento literário. Dessa forma, pensamos construir uma proposta de ação pedagógica que objetiva desenvolver competências leitoras dos alunos por meio do texto dramático.

Com foco na arte dramática, buscamos respostas, caminhos, observações sobre sua inserção na escola e, para isso, tomamos o texto dramático como uma forma de ampliar o número de leitores de textos literários. Aqui se coloca uma questão importante: por 
que não se discute o texto dramático nos cursos de formação de professores, no caso, nos cursos de Letras, Pedagogia e, até mesmo, História? Por que é tão pouco trabalhado nas escolas? Ao problemática implica em uma possibilidade de mudança na forma de lidar com a dramaturgia para crianças e jovens, de abertura de espaço de discussão para um tratamento diferenciado dessa manifestação artística no contexto escolar.

Acerca de uso, Rösing (2005, p. 15) comenta que o texto dramático não faz parte do universo do leitor brasileiro e, de modo mais acentuado, no âmbito escolar. Comumente seu uso está restrito ao universo de integrantes de grupos teatrais. Essa mesma ideia é apontada por Grazioli (2019) em seu estudo sobre a dramaturgia impressa para leitura da criança. $\mathrm{O}$ autor destaca em sua tese de doutorado que a dramaturgia também não é um tema recorrente nos estudos críticos de literatura infantil. Aponta alguns poucos estudos que tratam da dramaturgia voltada ao público infantil, dentre elas, a obra Teatro infantil: história, leitura e propostas (2015), de sua autoria e organização, e que recebeu da Fundação Nacional do Livro Infantil e Juvenil o selo "Altamente Recomendável”, bem como o de "Melhor Obra Teórica".

No texto Yes, nós temos teatro (2005, p. 144), Regina Zilberman destaca que "fazer teatro para crianças pode ser fácil e, ao mesmo tempo, difícil”. Assim,

[...] se entendermos o teatro desde a perspectiva dos textos originais criados por artistas brasileiros, deparamo-nos com uma produção não muito numerosa. Não por eles não terem sido escritos, mas porque nem todos chegam a ser publicados. Os que passaram pela imprensa e transformaram-se em livros, porém, bastam para garantir que dispomos de uma tradição de textos dramáticos dirigidos ao público mirim (ZILBERMAN, 2005, p. 145).

No caso de publicações nesse gênero, citamos Maria Clara Machado com Pluft, o fantasminha (1987); A bruxinha que era boa (2001); Cavalinho azul (1987); A menina e $o$ vento (1986), dentre outras. A autora oferece textos de grande valor e foi, possivelmente, quem mais explorou o gênero quando da formação e estabelecimento da dramaturgia e do teatro infantil no país, por volta da década de 1980, aliando fantasia poética, humor e profundo senso humanístico.

Carece de uma profunda discussão sobre a lacuna do texto dramático na escola e suas possibilidades de uso como meio de ampliação das habilidades de leitura. A leitura de Teatro de se ler: o texto teatral e a formação do leitor (2007), de Fabiano Tadeu Grazioli, nos leva a refletir sobre a formação de leitura de texto dramático e a interação entre o leitor e a atividade cênica. Nessas questões, destaca:

O texto teatral, ao contrário do que a escola vem demonstrando, não se destina a treinar entonação ou leitura em voz alta, mas a ser entendido como uma história a ser contada com uma estrutura diferenciada, e que pode ser atualizado, ou seja, representado. A escola deve proporcionar a introdução do aluno nesse universo e, desse modo, estabelecer uma ponte para o espetáculo teatral. Ao propor essa ponte, de maneira séria e competente, a escola estará possibilitando o diálogo do aluno com a realidade que está inserido, com o qual ele passará a compreendê-la e a querer agir, conscientemente, sobre ela. (GRAZIOLI, 2007, p. 114).

Em relação aos documentos oficiais, os Parâmetros Curriculares Nacionais (PCNs) e a BNCC recomendam a diversidade de textos, assinalando o gênero dramático como 
forma de ampliação de leitura e de experiência artística multissensorial. De acordo com a $\operatorname{BNCC}$ (2018, p. 198):

O teatro instaura a experiência artística multissensorial de encontro com o outro em performance. Nessa experiência, o corpo é lócus de criação ficcional de tempos, espaços e sujeitos distintos de si próprios, por meio do verbal, não verbal e da ação física. Os processos de criação teatral passam por situações de criação coletiva e colaborativa, por intermédio de jogos, improvisações, atuações e encenações, caracterizados pela interação entre atuantes e espectadores. $\mathrm{O}$ fazer teatral possibilita a intensa troca de experiências entre os alunos e aprimora a percepção estética, a imaginação, a consciência corporal, a intuição, a memória, a reflexão e a emoção.

A leitura do texto dramático prevê a vivência de jogos, improvisações e encenações que possibilitem a troca de experiências entre alunos e permitem aprimorar a percepção estética, a imaginação, a consciência corporal, a intuição, a memória, a reflexão e a estesia. Definidas em linhas gerais, é preciso que as linguagens artísticas das Artes visuais, da Dança, da Música e do Teatro "sejam consideradas em suas especificidades, as experiências e vivências dos sujeitos em sua relação com a Arte não acontecem de forma compartimentada ou estanque" (BNCC, 2018, p. 196). Da mesma forma, prever "o diálogo entre essas linguagens, o diálogo com a literatura, além de possibilitar o contato e a reflexão acerca das formas estéticas híbridas, tais como as artes circenses, o cinema e a performance" (BNCC, 2018, p. 196).

Dessa maneira, no nosso entender, é importante salientar que a leitura do texto dramático é uma maneira de aproximar o leitor do teatro. Se bem realizada e conduzida pelo professor pode conquistar um leitor e transformá-lo num apreciador de peças teatrais.

\section{Ruy Guerra e Chico Buarque: encontros}

O poeta, escritor, cineasta moçambicano Ruy Guerra, em 1952, estudou na França, no Instituto de Altos Estudos Cinematográficos, quando produziu o filme Les hommes et les autres. Anos mais tarde, no Brasil, integrou o movimento "Cinema Novo". Esteve à frente da direção da produção cinematográfica de Os cafajestes (1963), Os fuzis (1964) e Os deuses e os mortos (1970). Em 1975, Ruy Guerra retornou a Moçambique para participar da fundação do Instituto Nacional de Cinema. De volta ao Brasil, na década de 1980, dirigiu filmes que revelaram uma maior preocupação estética como A ópera do malandro (1985), peça musical adaptada do livro homônimo de Chico Buarque, e Kuarup (1988), de Antônio Callado. Seu último trabalho de direção deu-se no ano 2000, no filme Estorvo, baseado no livro do mesmo nome, de Chico Buarque (1991). Assim como Chico Buarque é laureado com inúmeras distinções, a última com o Prêmio Camões de Literatura, a mais importante premiação da língua portuguesa, Ruy Guerra, um dos principais nomes do cinema brasileiro, é também vencedor de grandes consagrações, com mais de uma centena de prêmios nacionais e internacionais.

Chico Buarque, por sua vez, em 1966, junto com Nara Leão, venceu com $A$ banda o II Festival de Música Popular, quando dividiu o $1^{\circ}$ lugar com Jair Rodrigues com Disparada. Foi em São Paulo, no auditório da TV Record, Canal 7, que o cantor, de cabelos comportadamente penteados, terno, gravata borboleta, de pé a tocar violão, com a perna direita apoiada em um banco que cantou a marchinha $A$ banda, mais tarde 
lançada em seu primeiro álbum Chico Buarque de Hollanda. Nara Leão, ao seu lado, formou a dupla que os amantes da Música Popular Brasileira daquela geração jamais esqueceram.

Assim como Ruy Guerra não nasceu em Calabar: o elogio da traição, Chico Buarque não nasceu em $A$ banda. Diante ao recorte por nós proposto para esta abordagem, destacamos, por exemplo, sua participação no cenário da dramaturgia ao musicar o poema Vida e morte Severina, do poeta pernambucano João Cabral de Melo Neto - auto de Natal pernambucano (1973, p. 193-205), escrito em 1954-1955.

A peça, apresentada em setembro de 1965 no Teatro Universitário da Universidade Católica de São Paulo (TUCA), recebeu aplausos por 10 minutos. Reverenciada pelo público e crítica especializada, no ano seguinte foi premiada no IV Festival de Teatro Universitário de Nancy, França. Chico Buarque participou dessa apresentação na cidade francesa como violonista do espetáculo. É a historiadora Carla Fernanda da Silva quem explica:

No TUCA, a primeira peça encenada foi Morte e Vida Severina, uma adaptação do poema João Cabral de Melo Neto e musicada pelo jovem Chico Buarque de Holanda. O grupo pretendia discutir a miséria do povo brasileiro oprimido pela Ditadura Militar, por meio da miséria do sertão nordestino exaltada no poema. A peça foi um enorme sucesso em sua estreia e demais apresentações. Logo em seguida, selecionada para o Festival de Teatro Universitário de Nancy (França), foi premiada como melhor peça, aumentando seu prestígio no Brasil. (SILVA, 2014, p. 1).

Após a decisão de musicalizar Morte e Vida Severina, Chico Buarque, então um estudante de 22 anos, contava com algumas composições e um compacto, com Pedro Pedreiro e Sonho de um Carnaval. Depois de sua primeira experiência no teatro, outros festivais, outras premiações, retorno a Europa, novos discos, shows, excursões. Ao se encontrar com o amigo cineasta e compositor moçambicano Ruy Guerra, Chico Buarque novamente se vê no teatro, dessa vez no Teatro Municipal de Santo André, em $O$ homem de la mancha, quando assinaram uma versão portuguesa para a trilha sonora da peça (ZAPPA, 2011).

Aos palcos do teatro, Chico Buarque levou cenas da política brasileira do Estado ditatorial. No campo da dramaturgia, o conjunto de sua obra, por se posicionar contrário ao regime civil-militar vigente, é considerado uma das vertentes mais destacadas de sua produção entre os anos de 1970 e 1980. Isso porque o caráter político social permeou a obra teatral buarqueana (e também grande parte de suas composições musicais), pois um número expressivo de suas peças foi escrita e encenada pela primeira vez entre os anos de 1968 a 1975, os mais violentos da ditadura militar.

Os biógrafos de Chico Buarque são unânimes em afirmar que seus textos dramaturgos responsabilizaram-se pelo desenvolvimento de sua carreira. E, ainda, o levaram ao Chico Buarque romancista, ganhador de inúmeros prêmios: o livro-poema $A$ bordo do Rui Barbosa (1981), Fazenda Modelo: novela pecuária (1975), Chapeuzinho amarelo (1982), Estorvo (1991), Benjamim (1995), Budapeste (2003), Paratodos (2005), Leite Derramado (2009) e Meu irmão alemão (2014). Na trajetória dramatúrgica de Chico Buarque estão Calabar: o elogio da traição (1974, com Ruy Guerra), Gota d'água (1975, com Paulo Pontes), Ópera do malandro (1978) e Os saltimbancos (2002). Nesse conjunto deixou um legado musical à sua carreira, pois alguns de seus clássicos integram trilhas sonoras dessas peças teatrais: Roda-viva, 
Tatuagem, Gota d'Água, Geni e o Zepelim, Bárbara e tantas outras.

A trajetória de Ruy Guerra e Chico Buarque é marcada por encontros. Iniciados em Calabar: o elogio da traição, o moçambicano, que ainda mantém sotaque português, e o carioca da gema entrelaçam-se na literatura, no cinema, no teatro. Juntos, reescreveram o período do domínio da Espanha sobre Portugal, união ibérica transcorrida entre os anos de 1580 a 1640, e suas consequências para o Brasil Colônia, em especial para a vida de Domingos Fernandes Calabar. Liderados por Mathias de Albuquerque, governador das capitanias de Pernambuco, Itamaracá, Paraíba e Rio Grande, os primeiros anos de ocupação foram marcados por conflitos entre holandeses e senhores de engenho. Nesse contexto que surgiu Calabar, senhor de engenho nascido em Porto Calvo, Capitania de Pernambuco, hoje Alagoas, "perfeito conhecedor do terreno onde se travavam os combates" (FAUSTO, 2007, p. 85) e que inicialmente lutou contra os holandeses para depois apoiá-los. Os motivos pelos quais levaram Calabar desertar das tropas lusas para integrar as milícias holandesas são ainda questionados por historiadores, especialmente pela carência de fontes primárias. Contudo, a pecha de traidor que recebeu dos colonos portugueses perdura até os dias de hoje, mesmo que Calabar não tenha sido o único a ser visto como traidor dos portugueses. "Vários senhores de engenho e lavradores de cana, cristãos-novos, negros escravos, índios tapuias, mestiços pobres e miseráveis estiveram ao lado dos holandeses." (FAUSTO, 2007, p. 89). Ainda que não se possa comprovar, o estudo Calabar (traidor, vilão ou idealista?), de Flávio Guerra, apresenta um fragmento de uma carta escrita por Calabar, em resposta a Mathias de Albuquerque depois de oferecer anistia, restituição dos bens confiscados pela Espanha (engenhos de Comadatuda e Escurial) e o reingresso nas tropas portuguesas como oficial. Na carta, o acusado expôs suas razões para estar ao lado dos holandeses:

Os holandeses têm provado, melhor que os portugueses e espanhóis, que nas terras por vós ocupadas há a mais negra escravidão e tirania. Eles não somente protegem materialmente os naturais de seu país, como lhe dão até a liberdade de consciência. Em Recife e Olinda cada um pensa como quer. E entre vós? Vós bem sabeis. Com o mesmo ardor e sinceridade com que me bati pela vossa bandeira, me baterei pela bandeira da liberdade do Brasil, que agora é a holandesa. Tomo Deus por testemunha de que meu procedimento é o indicado pela minha consciência de verdade patriota. Depois de ter derramado meu sangue pela causa da escravidão, que é a que defendeis ainda, passei para este campo, não como traidor, mas como patriota. (GUERRA, 1986, p. 45).

Contudo, se Calabar escreveu ou não essa carta, supostamente encontrada em um arquivo em Haia, Holanda, a alcunha de traidor permanece agarrada à sua imagem. Comumente ouve-se atribuir ao nome Calabar àquela pessoa que cometeu deslealdade a outrem, mesmo que a historiografia tenha revisitado os fatos que envolveram sua figura nas lutas entre portugueses e holandeses; mesmo que "escravos que fugiram dos seus donos para obter mais liberdade entre os holandeses, de grupos de índios tupis que deles se aproximaram, e também de soldados napolitanos que debandaram para o lado invasor" (SCHALKWIJK, 2000, p. 1); mesmo que Chico Buarque e Ruy Guerra tenham vestido o colono de Porto Calvo com outras roupagens ao colocarem em discussão o termo traidor em associação ao regime civil-militar brasileiro e à figura do guerrilheiro Capitão Carlos Lamarca, um dos líderes da luta armada contra a ditadura instaurada no país em 1964, também um desertor do Exército brasileiro. Em Calabar: o elogio da 
traição, a peça faz uma vinculação "com o país dos militares e, ainda, uma analogia entre os militares Calabar e Lamarca, o capitão do exército que desertara em 1969 para integrar a guerrilha armada." (SILVA, 2004, p. 74-75).

Até baixar totalmente o pano da cortina, o elenco de Calabar: o elogio da traição (1974, p. 137) canta:

O que é bom pra Holanda é bom pro Brasil/ O que é bom pra Luanda é bom pro Brasil/ O que é bom para Espanha é bom pro Brasil/ O que é bom pra Alemanha é bom pro Brasil/ O que é bom pro Japão é bom pro Brasil/ O que é bom pro Gabão é bom pro Brasil/ O que é bom pro galego é bom pro Brasil/ O que é bom pro grego é bom pro Brasil/ O que é bom pra troiano é bom pro Brasil/ O que é bom pra baiano é bom pro Brasil/ $\mathrm{O}$ que é bom pra inglês é bom pro Brasil/ O que é bom pra mamãe é bom pro Brasil/ O que é bom pro neném é bom pro Brasil/ O que é bom pra fulano é bom pro Brasil [...]

\section{Arte cênica para juventude: teatro na escola}

Mesmo que haja uma crescente admissão de que um olhar unidisciplinar não seja bastante considerável à obtenção de uma melhor compreensão de processos, fenômenos e acontecimentos, o diálogo interdisciplinar ainda consiste em um grande desafio nas instituições de ensino. Romper fronteiras entre as disciplinas requer coragem. Isso porque se faz oportuno para a construção e articulação de saberes que atendam necessidades dos tempos atuais.

Nesse cenário educacional, intentamos ações didático-pedagógicas aos Anos Finais do Ensino Fundamental, mais especificamente ao $7^{\circ}$ ano, que privilegiem textos dramatúrgicos escritos por autores nacionais em diálogo com a História do Brasil. A escrita dramatúrgica, nesse caso, não pretende de forma alguma substituir a escrita histórica da invasão holandesa no Nordeste brasileiro, sequer em sentido inverso. Essa complementaridade quer, diante ao desenvolvimento cênico de uma ou mais ações, libertar o texto histórico do rigor formal, no emprego de um vocabulário específico do texto literário. Isso, certamente, vai ao encontro, em certa medida, à expectativa estética do alunado juvenil, público alvo de nossa proposta.

De acordo com a BNCC (2018), o que se quer é possibilitar aos alunos dos Anos Finais do Ensino Fundamental (e também do Ensino Médio) condições propícias à interação com manifestações artísticas, produções culturais e arte literária. Ao reagir e agir em prol de um crescimento tanto individual como coletivo dos alunos, acreditamos que o ensino-aprendizagem da Arte nas escolas torna-se necessário ao complemento da formação de indivíduos críticos e sensíveis diante à realidade que o cerca. A multiplicidade de relações que nos é colocada à frente, a todo instante, nos leva a fazer uso do texto dramatúrgico como elemento metodológico ao ensino dos Anos Finais do Ensino Fundamental, especialmente nas disciplinas de História e Língua Portuguesa.

Essas entendidas, ainda, por muitos, que para a compreensão de seus conteúdos, aprender de cor consiste no principal suporte metodológico à aprendizagem. Ao percorrer um caminho inverso da prática da "decoreba", busca-se a superação de métodos e práticas pautados na memorização, o que sem dúvida torna enfadonho o estudo de inúmeros componentes da Língua Portuguesa e da História do Ensino Fundamental e do Ensino Médio. Nessa linha de pensamento, o teatro no espaço da sala de aula se apresenta de maneira ímpar ao promover uma educação acurada do olhar, da escuta. 
Adentramos em Calabar: o elogio da traição (1974) para sugerirmos uma proposta interdisciplinar de ensino-aprendizagem, na aproximação dos componentes curriculares de Língua Portuguesa e de História do $7^{\circ}$ Ano do Ensino Fundamental, momento em que são estudadas as conexões entre Europa, América e África. Instigamos que, após o professor expor à vista dos alunos o livro em epígrafe, passado de mão em mão, fragmentos biográficos de Chico Buarque e Ruy Guerra sejam dados a conhecer. Nada impede ao desenvolvimento da ação que o ambiente da sala de sala possa ser preenchido com a trilha sonora que compõe a peça teatral, composta por Cobra-devidro, Bárbara, Tatuagem, Fado tropical, Ana de Amsterdam, Bárbara, dentre outras. Ao pensar na carga-horária ofertada à disciplina de História, sem um tempo disponível aos ensaios teatrais, a trilha sonora também pode ser um caminho alternativo para uma revisão dos conteúdos da história da invasão holandesa no Brasil e de seus principais personagens.

Em seguida, a turma, que já estudou nas aulas de História as conexões entre Europa, América e África durante o período colonial, passa a conhecer os personagens da peça para, quem sabe, ao final do ano letivo, possam assumir seus papéis em uma apresentação teatral. Nesse momento, torna-se oportuno que o alunado se inteire da composição da estrutura, da poética e da leitura de textos dramatúrgicos, ainda tão pouco adotados no Ensino Fundamental. O professor, imbuído de levar o estudo da dramaturgia como elemento metodológico para o ensino de História e da Linguagem, ministra aulas expositivas dialogadas para apresentar os personagens da peça de Chico Buarque e Ruy Guerra, bem como a literatura dramática como gênero textual. Por ser o texto dramático voltado à encenação, pode apresentar uma divisão de atos e cenas, previamente estabelecida, com o número de aulas já definido.

Propomos também que Calabar: o elogio da traição seja disponibilizado à turma, de forma resumida, para que a mesma possa fazer, com o auxílio do professor, uma análise comparativa com o texto do livro didático, até mesmo da alcunha de traidor dada a Calabar. As personagens precisam ser elencadas aos alunos, acompanhadas de uma brevíssima biografia, com o intuito de serem identificadas com os personagens do livro didático de História. O professor deve, ainda, dar a conhecer à turma o recorte temporal do texto dramático em mãos, bem como o contexto histórico em que Chico Buarque e Ruy Guerra escreveram o livro.

No conjunto, esses recursos metodológicos facilitam a compreensão de um texto dramático, tão pouco presente no hábito da leitura. Ao término do Ensino Fundamental, ao se depararem com desafios de maior complexidade, os alunos, especialmente no que diz respeito à necessidade de experimentarem lógicas diferentes de organização dos conhecimentos relacionados às áreas de História e Língua Portuguesa, o texto dramatúrgico consiste em um excelente recurso metodológico ao ensino-aprendizagem nos vários componentes curriculares.

\section{Cai o pano: considerações finais}

Próximo ao término do texto dramático de Chico Buarque e Ruy Guerra (1974, p. 133), depois de saber o destino de seu amado Calabar, Bárbara, que ao longo de toda peça defende a imagem do condenado, conjetura:

Um dia este país há de ser independente. Dos holandeses, dos espanhóis, portugueses... Um dia todos os países poderão ser independentes, seja lá do que for. Mas isso requer muito traidor. Muito Calabar. E não bastar enforcar, retalhar, picar... Calabar não morre. 
Calabar é cobra-de-vidro. E o povo jura que cobra-de-vidro é uma espécie de lagarto que quando se corta em dois, três, mil pedaços facilmente se refaz.

Na cidade do Rio de Janeiro, na noite do dia 8 de novembro de 1973, o pano do palco do Teatro João Caetano, que estrearia a peça Calabar: o elogio da traição, de Chico Buarque e Ruy Guerra, não foi descerrado. Com lotação esgotada para a estreia e mais quatro sessões já vendidas, por determinação do general Antônio Bandeira, então diretor-geral da Polícia Federal, o espetáculo produzido por Fernando Torres foi interditado e, assim, permaneceu por sete anos.

Calabar: o elogio da traição é uma obra da dramaturgia brasileira escrita no período mais repressivo do regime civil-militar. Teve o intento de abordar o conceito de traição na figura de Domingos Fernandes Calabar, homem que deixou os portugueses para ficar ao lado dos holandeses na conquista de parte do Nordeste brasileiro no século XVII. Como explícito no título, a peça teatral quer pôr à prova a história oficial, na bipolarização realidade-ficção para conseguir desconstruir discursos do tempo pretérito, com os pés no presente. As personagens, numa cronologia história completamente alheia àquela apresentada na história positivista e, até mesmo, nos livros didáticos de História, percorrem caminhos distintos. Isso porque Calabar, aos olhos de Buarque e Guerra, é visto diferentemente por cada um dos atores, como lhes convém. O julgamento fica por conta do espectador, do aluno. A "verdade histórica" começa a ruir.

Levar Calabar: o elogio da traição para os alunos dos Anos Finais do Ensino Fundamental, mais precisamente ao $7^{\circ}$ Ano, consiste em um desafio ao professor, tendo em conta que em raríssimos momentos a literatura dramática aparece em sala de aula, mesmo que a BNCC propicie um espaço para essa prática de linguagem. O nosso interesse surgiu em função da falta de espaço reservado ao texto dramático na sala de aula, que tem ficado à margem nas aulas de Linguagem em virtude da matriz curricular e da formação de professores que, ao chegarem na sala de aula, não se sentem preparados para o trabalho com o texto dramático. Para propor uma transformação nessa prática, sugerimos a leitura do gênero dramático, a fim de despertar nos alunos novas formas de expressão, entendendo essa experiência como algo de inegável valor educacional.

O espaço escolar deve estar atento à promoção de práticas diversificadas, a fim de que os alunos aprendam a ler e interpretar, a fazer analogias entre textos históricos e ficcionais "que lhes permitam ampliar suas capacidades expressivas em manifestações artísticas, corporais e linguísticas, como também seus conhecimentos sobre essas linguagens [...]. (BNCC, 2018, p. 65). Os alunos, "por meio das diferentes linguagens, como a música, a dança, o teatro, as brincadeiras de faz de conta [...] se comunicam e se expressam no entrelaçamento entre corpo, emoção e linguagem." (BNCC, 2018, p. 41).

Nossa proposta em levar a dramaturgia para a juventude atende uma proposta de enriquecer os conhecimentos históricos referentes à invasão holandesa em terras brasileiras e na área da Linguagem. E, com vistas ao letramento literário, visa uma ampliação e diversificação de práticas de leitura à vivência do alunado no campo das manifestações artístico-literárias. Essa metodologia possibilita um alargamento da compreensão e do experimento da diversidade cultural brasileira. Ainda leva o aluno ao universo da arte e da literatura como caminhos profícuos ao conhecimento e ao reconhecimento de diferentes maneiras de ser, pensar, agir, reagir, sentir, bem como no confronto do diverso, a desempenhar atitudes de valorização e de respeito à diversidade (BNCC, 2018). 
A obra dramaturga Calabar: o elogio da traição, de Chico Buarque e Ruy Guerra, consiste em um caminho profícuo à aprendizagem de fatos recorrentes na história do Brasil, ainda que pouco usual ao se tratar de Ensino Fundamental. A proposta, sem dúvida, é desafiadora. Mas, uma gestão participativa, uma parceria que conta com alunos, professores, pais e comunidade escolar pode traçar um caminho que possibilite a concretização da atividade que propõe o teatro na escola. Esperamos que este texto possa abrir debates e reflexões entre os diversos leitores e que, sobretudo, os professores possam subsidiar uma discussão a respeito do texto dramático em seus múltiplos aspectos, sempre buscando o aperfeiçoamento da leitura de seus alunos.

\section{Referências}

BNCC. Base Nacional Comum Curricular. 2018. Disponível em: http://basenacionalcomum.mec.gov.br/images/BNCC_EI_EF_110518_versaofinal_site. pdf. Acesso em: 23 mar. 2019.

BUARQUE, C. Fazenda modelo: novela pecuária. 6a . ed. Rio de Janeiro: Civilização Brasileira, 1975 (Coleção Vera Cruz, Literatura brasileira, 191).

28). . Gota d'água. Rio de Janeiro: Civilização Brasileira, 1975 (Coleção teatro hoje, . Ópera do malandro. São Paulo: Círculo do Livro, 1978. 1982.

. Chapeuzinho amarelo. Rio de Janeiro: Berlendis \& Vertecchia Editores LTDA., . Estorvo. $7^{\mathrm{a}}$. impres. São Paulo: Companhia das Letras, 1991.

Budapeste: romance. São Paulo: Companhia das Letras, 2003.

. Leite derramado. São Paulo: Companhia das Letras, 2009.

. Meu irmão alemão. São Paulo: Companhia das Letras, 2014.

. (adap.). Os saltimbancos. São Paulo: Global Editora, 2002 (Peça teatral, 5).

BUARQUE, C.; GUERRA, R. Calabar: o elogio da traição. São Paulo: Círculo do Livro, 1974.

BUARQUE, C.; KEATING, V. A bordo do Rui Barbosa. Rio de Janeiro: Palavra e Imagem, 1981.

FAUSTO, B. História do Brasil. 12ª . ed. $2^{\mathrm{a}}$. reimp. São Paulo: Editora da Universidade de São Paulo, 2007 (Didática, 1).

GRAZIOLI, F. T. O teatro de se ler: o texto teatral e a formação do leitor. Passo Fundo: Ed. UPF, 2007. 
- Percursos criativos na concepção de Canto de Cravo e Rosa, de Viviane Juquero: a dramaturgia impressa para a leitura da criança. Tese (Doutorado em Letras) Programa de Pós-Graduação em Letras, Universidade de Passo Fundo. Passo Fundo, 2019.

. (org.). Teatro infantil: história, leitura e propostas. Curitiba: Positivo: 2015.

GUERRA, F. Calabar (traidor, vilão ou idealista?). Acontecimentos ocorridos durante princípios do século XVII - Invasão holandesa. Recife: Asa Pernambuco, 1985.

HOLANDA, C. B. de. Benjamim. São Paulo: Companhia das Letras, 1995).

HOLlandA, C. B. de. Paratodos. São Paulo: Evoluir, 2005 (Coleção cante esta história, 3).

LE GOFF, J. História e memória. 2a . ed. Campinas: Editora da Unicamp, 1992.

MELO NETO, J. C. de. Antologia poética. 2a . ed. Rio de Janeiro: José Olympio Editora; Sabiá, 1973.

MACHADO, M. C. O cavalinho azul. 5a . ed. Rio de Janeiro: Agir, 1982.

A menina e o vento. $7^{\mathrm{a}}$. ed. Rio de Janeiro: Agir, 1986.

. Pluft, o fantasminha. $2^{\text {a }}$. ed. Rio de Janeiro: Agir, 1987

. A bruxinha que era boa. São Paulo: Companhia das Letrinhas, 2001.

NUNES, E. F. A reescrita da história em Calabar, o elogio da traição de Chico Buarque e Ruy Guerra. Brasília, 2002. 144h. Dissertação (Mestrado em Literatura Brasileira) - Departamento de Teoria Literária e Literaturas, Universidade de Brasília, Brasília.

RAMOS, F.; MIRANDA, L. F. Enciclopédia do cinema brasileiro. $3^{\mathrm{a}}$. ed. rev. e atual. São Paulo: Senac, 2012.

RÖSING. T. M. Apresentação. In: SITTA, M.; POTRICH, C. Teatro: espaço de educação, tempo para a sensibilidade. Passo Fundo: Ed. Da UPF, 2005.

SCHALKWIJK, F. L. "Por que, Calabar?” O motivo da traição. In: Revista Fides Reformata, v. 5, n. 1, 2000, p. 1-16.

SILVA, F. de B. e. Chico Buarque. São Paulo: Publifolha, 2004 (Folha explica).

VAINFAS, R. (dir.). Dicionário do Brasil Colonial (1500-1808). Rio de Janeiro: Objetiva, 2000.

ZAPPA, R. Para seguir minha jornada: Chico Buarque. Rio de Janeiro: Nova Fronteira, 2001. 
ZILBERMAN, R. Yes, nós temos teatro. In: Como e por que ler a literatura infantil brasileira. Rio de Janeiro: Objetiva, 2005.

Recebido em 02 de junho de 2019

Aceito em 26 de junho de 2019 